\title{
Learning Strategies of Arabic Language Vocabulary for Pre-University Students' in Malaysia
}

\author{
Harun Baharudin $^{1} \&$ Zawawi Ismail ${ }^{1}$ \\ ${ }^{1}$ Faculty of Education, Universiti of Malaya, Malaysia \\ Correspondence: Harun Baharudin, Faculty of Education, Universiti of Malaya, Malaysia. E-mail: \\ harunbaharudin@yahoo.com.my
}

Received: June 9, 2014 Accepted: January 20, 2015 Online Published: April 20, 2015

doi:10.5539/ass.v11n10p32 URL: http://dx.doi.org/10.5539/ass.v11n10p32

\begin{abstract}
Vocabulary is a vital aspect in second language learning. The knowledge and mastery of vocabulary are able to give a direct effect on learning and mastery of a second language. The learning of Arabic language in Malaysia has also put the mastery of Arabic language vocabulary as the main goal. The aim of this survey is to explore the learning strategies of Arabic language vocabulary of pre-university students in Malaysia. The objectives of this study are to (a) measure the vocabulary learning strategies (VLS) usage level of pre university students, (b) to identify the highest strategy usage for each main vocabulary learning strategy (VLS) and (c) to identify the lowest strategy usage for each main vocabulary learning strategy (VLS). Questionnaires are used as the instrument which is developed based on the Schmitt's VLS classification (1997). The sample involved 742 students in 15 religious high school (SMKA) and government-aided religious school (SABK). The study found that pre-university students have been using vocabulary learning strategies (VLS) moderately. Generally, the students used the determination strategy with the highest frequency compared to other strategies whilst the cognitive strategy is the least optimized one. Six strategies are used regularly while 12 strategies are not used frequently. The findings show that pre-university students tend to use strategies that are simpler, not creative and do not require high level of thinking. This situation somehow has displayed that the learning of Arabic language vocabulary in Malaysia is still very far from achieving the vocabulary learning objectives.
\end{abstract}

Keywords: vocabulary learning strategies (VLS), Arabic language vocabulary, second language learning, and the mastery of Arabic language vocabulary, pre-university

\section{Introduction}

Vocabulary is the key aspect in language learning. It has become the basic requirement and is prioritized compared to other linguistics aspects (Talib, 2000; Omar, 1984). In other words, the marginalization of the role of vocabulary may affect the mastery of other language skills. This has been acknowledged by Hunt \& Berglar (2005) who implied that lexical knowledge is the core of understanding and language usage. Tu'aymah (1986) also mentioned lexical knowledge as the major condition in mastering a language.

Various efforts have been implemented in helping students to improve on their Teaching \& Learning (T\&L) vocabularies. Sokmen (1997) has asserted that the efforts executed to explore the vocabulary aspects are able to assist the students in learning all the vocabulary needed in the class. Cunnings worth (1995) agreed that these efforts are great approaches in assisting the students. Those efforts started with the exploration of aspects in the target problem and product and finally tackle the process aspect.

The exploration in understanding the vocabulary learning process has finally brought into the research of vocabulary learning strategies (VLS) which has seen through the involvement of students in the vocabulary learning process. Vocabulary Learning Strategies (VLS) were originally known as one of the language learning strategies (LLS) sub strategies. However, a few researchers are of the view that the importance of VLS is seen as more prominent than language learning strategy (LLS) in second language learning (Ahmed, 1989; Kojic-Sabo \& Lightbown, 1999; Schmitt, 1997). Vocabulary learning strategies (VLS) research orientation that viewed the individual strategy's effectiveness in vocabulary learning has helped the students in self-making choice, self-monitoring and self-assessment. This allows the students to apply the cognitive process strategy in strengthening the relationship between vocabulary learning strategies and achievement $(\mathrm{Gu}, 2005$; Macaro, 2005). 


\section{The Classification of Vocabulary Learning Strategies}

Vocabulary learning strategies are the methods used by the students in learning vocabulary. There are various classifications of vocabulary learning strategies (VLS) suggested among the researchers like Cohen (1990), Nation (2001), Schmitt (1997) and Brown \& Payne (1994). Schmitt's classification is one of the classifications widely used among researchers. This classification system is one of the most crucial contributions in the terms of the provision of general classification framework for vocabulary learning strategies. It has the comprehensive features in most learning aspects of vocabulary. This classification system is based on the discovery, consolidation and categorized system (Oxford, 1990) in language learning strategies (LLS).

Generally, Schmitt has classified the vocabulary learning strategies into two primary groups which are a) discovery strategies, and b) consolidation strategies. The discovery strategies involved the early stage of learning towards the meaning of new words found whereas the consolidation strategies involved the learning activity and remembering the word meanings which are already known.

These two main strategies are seen as similar to the different concept of Nation (1990) between the 'enhancement of vocabulary' strategy and 'reinforcement of vocabulary' strategy. Enhancing the vocabulary is when the students learn new words and then start their learning while reinforcing the vocabulary is to build and strengthen the prior knowledge that already existed.

The vocabulary learning strategies (VLS) in Schmitt's classification model is also available in the second layer under two major strategies which are determination strategy, social strategy, memory strategy, cognitive strategy and meta-cognitive strategy. The determination and social strategies are put under the discovery strategies group whilst social, memory, cognitive and meta-cognitive strategies come under the group of consolidation strategies.

Based on this statement, this study has used Schmitt's VLS classification as the basis of the study. It has been developed in accordance with Oxford's (2003) classification of language learning strategies. This study has also used the pre-university students who have studied Arabic language as the sample of studies. The usage of this VLS classification is divided into a few factors such as efficiency, motivation and culture (Schmitt, 2000). This is because the culture and environment may affect students' choices of appropriate vocabulary learning strategies (Schmitt, 2000).

\section{Objectives}

The main objective of this study is to identify the vocabulary learning strategy (VLS) usage among pre-university students in religious high schools (SMKA) and government-aided religious schools (SABK) in Malaysia. The objectives of this study are to: a) identify the degree of VLS usage among the religious high school students, b) identify the main five of strategies that have the highest and lowest usage of vocabulary learning strategies (VLS), and c) identify the types of sub strategies that have high and low usage of vocabulary learning strategies (VLS).

Based on the study objectives, the research questions of the study are as follows:

1) What is the level/degree of main vocabulary learning strategies (VLS) usage of pre-university students?

2) What is the main of five strategies that has the highest usage for each main vocabulary learning strategy (VLS)?

3) What is the sub strategy that has the lowest usage for each main vocabulary learning strategy (VLS)?

\section{Research Methodology}

The design of this study is the survey that used questionnaires based on the Arabic Vocabulary Learning Strategies. The questionnaire was created and modified based on Bannett's (2006) vocabulary learning strategies questionnaires set which have been adapted from Schmitt's (1997, 2000) vocabulary learning strategies questionnaires set. The questionnaires contain 54 questions involving five key strategies which are determination, social, memory, cognitive and meta-cognitive strategies.

This study involved the Form Six students in 15 religious high schools (SMKA) and government-aided religious schools (SABK) all over Peninsular Malaysia. These schools are divided into four zones which are north, south, east and west. A total of 742 Form Six students in SMKA and SABK participated. Students are given the questionnaires in order to obtain the data. The questionnaires have gone through the validity and reliability process first and have been pilot tested in a religious high school in Pahang, Malaysia. The questionnaire instrument obtained a .94 Cronbach alpha value and this has shown its reliability at the highest level. 


\section{Results}

The result of the study indicated the overall mean for VLS item is 2.85 with a standard deviation of 0.47 which is at intermediate level. The results show that the level of VLS usage among the students of SMKA is moderate. It also shows that the whole main category of VLS is at an intermediate level. Table 1 shows the analysis for the main score of the main strategies of VLS with determination strategy having the highest score $(M=3.03, S D=$ $0.58)$, social strategy $(M=2.97, S D=0.58)$, memory strategy $(M=2.80, S D=0.52)$, metacognitive strategy $(M$ $=2.77, S D=0.69)$ and cognitive strategy $(M=2.66, S D=0.62)$.

With these results, the main VLS that is most used is determination strategy while the cognitive strategy is the main strategy that is the least used by students.

Table 1. mean and standard deviation of VLS usage according to main strategy category ( $\mathrm{N}=742)$

\begin{tabular}{llll}
\hline Main Vocabulary Learning Strategy (VLS) & Mean & SD & Interpretation \\
\hline Determination & 3.02 & 0.58 & Intermediate \\
Social & 2.97 & 0.58 & Intermediate \\
Memory & 2.80 & 0.52 & Intermediate \\
Meta cognitive & 2.76 & 0.59 & Intermediate \\
Cognitive & 2.66 & 0.62 & Intermediate \\
Total & $\mathbf{2 . 8 5}$ & $\mathbf{0 . 4 7}$ & Intermediate \\
\hline
\end{tabular}

The results also found that there are six VLS items which are at a high usage level; representing $11 \%$ from all items, 36 items at an intermediate usage level which represent $67 \%$ of all items while 12 items are at a low usage level representing $22 \%$ of the total number of items.

Findings of this study show that the six most used strategies are "memorizing certain words based on the frequency of usage (very frequent/seldom/never)" $(M=4.07, S D=0.97)$, "asking classmates about the definitions of new words" $(M=3.87, S D=0.91)$ "pronouncing the words while ignoring the lines at their ends" ( $M=3.73, S D=1.11)$, "using Arabic-Malay dictionaries" $(M=3.64, S D=0.99)$, "guessing the definitions of words based on sentence context or the situation of the conversation" $(M=3.49, S D=0.97)$ and "asking teachers to find out the definitions of new words" $(M=3.47, S D=0.96)$. All these strategies are at a mean between 3.49 to 4.07 which is at a high frequency level of usage.

Table 2. VLS that are most frequently used

\begin{tabular}{|c|c|c|c|c|}
\hline Main strategy & Sub strategies & Mean & $S D$ & Interpretation \\
\hline Memory & $\begin{array}{l}\text { memorizing certain words based on the frequency of } \\
\text { usage }\end{array}$ & 4.06 & 0.96 & High \\
\hline Social & asking classmates about the definitions of new words & 3.87 & 0.91 & High \\
\hline Memory & $\begin{array}{l}\text { pronouncing the words while ignoring the inflections at } \\
\text { their ends }\end{array}$ & 3.73 & 1.11 & High \\
\hline Determination & using Arabic-Malay dictionaries & 3.64 & 0.99 & High \\
\hline Determination & $\begin{array}{l}\text { guessing the definitions of words based on sentence } \\
\text { context or the situation of the conversation }\end{array}$ & 3.50 & 0.97 & High \\
\hline Social & asking teachers to find out the definitions of new words & 3.47 & 0.96 & High \\
\hline
\end{tabular}

The mean gained for the whole item also shows that there are 12 strategies seldom used by respondents. The strategies are "using Arabic-Arabic dictionaries" $(M=1.77, S D=0.90)$, "using flash cards to record the words" ( $M=2.01, S D=0.93$ ), "using rhyming method (rhythmic sounds)" $(M=2.10, S D=0.93)$, "interacting and using the words with those who can speak the Arabic language" $(M=2.15, S D=0.86)$, "writing a few paragraphs of sentences using some of the words" $(M=2.15, S D=0.90)$, "putting labels in the Arabic language on physical objects" $(M=2.16, S D=0.89)$, "acting out the words into actions" $(M=2.18, S D=0.98)$, "making my own definitions of the words" $(M=2.25, S D=1.02)$, "testing oneself with vocabulary test" $(M=2.27, S D=0.90)$, "connecting the words to personal experiences" $(M=2.31, S D=0.90)$, "using the words while interacting with 
friends in using social websites" $(M=2.34, S D=1.05)$ and "learning the words from textbooks before the learning session" $(M=2.39, S D=0.92)$. The overall mean score for VLS is at the mean scale of 1.77 to 2.15 which is at a low interpretation level.

Table 3. VLS strategies that are not frequently used

\begin{tabular}{|c|c|c|c|c|}
\hline Main strategy & Sub strategy & Mean & $S D$ & Interpretation \\
\hline Determination & using Arabic-Arabic dictionaries & 1.77 & 0.90 & Low \\
\hline Memory & using flash cards to record the words & 2.01 & 0.93 & Low \\
\hline Memory & using rhyming method (rhythmic sounds) & 2.10 & 0.93 & Low \\
\hline Social & $\begin{array}{l}\text { interacting and using the words with those who can speak } \\
\text { the Arabic language }\end{array}$ & 2.15 & 0.86 & Low \\
\hline Memory & $\begin{array}{l}\text { writing a few paragraphs of sentences using some of the } \\
\text { words }\end{array}$ & 2.15 & 0.90 & Low \\
\hline Cognitive & putting labels in the Arabic language on physical objects & 2.16 & 0.89 & Low \\
\hline Memory & acting out the words into actions & 2.18 & 0.98 & Low \\
\hline Memory & making my own definitions of the words & 2.25 & 1.02 & Low \\
\hline Meta cognitive & testing oneself with vocabulary test & 2.27 & 0.90 & Low \\
\hline Memory & connecting the words to personal experiences & 2.31 & 0.90 & Low \\
\hline Social & $\begin{array}{l}\text { using the words while interacting with friends in using } \\
\text { social websites }\end{array}$ & 2.34 & 1.05 & Low \\
\hline Cognitive & $\begin{array}{l}\text { learning the words from textbooks before the learning } \\
\text { session }\end{array}$ & 2.39 & 0.92 & Low \\
\hline
\end{tabular}

\section{Discussion and Implications of the Study}

The study finds that pre-university students use the Arabic language VLS at a moderate level. This moderate usage level does not exceed mean value of 3.0 and is close to the low level. The findings also show that most students do not exploit a few strategies in learning Arabic vocabulary. Only five strategies which represent $11 \%$ are used frequently. These strategies are identified as popular strategies and regularly used by students in learning a second language. Most strategies that are advanced, modern, involve challenging learning activities, require in-depth mental activities, need help from supporting materials such as social media are not explored to the maximum level by the students. This is related to their lack of exposure to VLS, and lack of supporting materials which cause the students to not explore much on the other strategies to strengthen their vocabulary learning.

Results of this study are found to align with a few other studies conducted in Malaysia. Among them are those done by Nurazan Mohd. Rouyan (2004) and Ahmad Iskandar Haron (2008). At the same time, the findings are found to be similar to a few of those done overseas like Zarafshan (2002), Sarani \& Kapifour (2008) and Kapifour (2010) that found second language students to be moderate users of VLS.

The main strategy of VLS which is the most used by students in learning Arabic vocabulary is the determination strategy. The findings of this study are consistent with a few other studies such as Sahbazian (2004), Wan Nazri Wan Mohd Salleh (2006), Kapifour (2010), Celik \& Toptas (2010), all of which found that the determination strategy is a frequent strategy used by students in learning a second language. Among the most frequently used strategy items in the determination strategy is referring to Arabic-Malay dictionaries and guessing the definitions based on sentence or conversation context. However, other strategy items in this category have low usage level. This strategy involves speaking compartment analysis, words derivations and root word analysis, referring to the first language cluster, image or related signal analysis. These strategies require a strong mastery of the Arabic language especially in grammar (nahu) and morphology (sorof).

Meanwhile, the cognitive strategy is the VLS with the lowest level of usage among pre-university students. This situation shows that students do not have the tendency to manipulate the mental aspect. According to Misnan Jemali (1999), students who are weak in the Arabic language are found to use learning techniques such as memorizing, discussions and doing exercises. This finding is similar to that in studies done by Lio (2002) Kamarul Shukri (2009), Kapifour (2010), as well as Celik \& Toptas (2010). 
There are six VLS which are used at a high frequency level. The items of this strategy involve only three main strategies which are the determination, social and memory strategies. These strategies are included in those which are popular, simple and direct strategies in determining word meaning without using in-depth mental processing. They do not need a high creativity level and do not require much thinking process. This can be seen through a few strategies such as memorizing words based on regularity, using bilingual dictionaries, guessing the definition, as well as asking friends and teachers.

Findings on using bilingual dictionaries and guessing the definition are consistent with the study done by Zhang (2009), Ab. Halim Mohamad \& Wan Mohamad Wan Sulong (2006), and Hsien-jen (2001). Dictionary usage refers to the understanding of contextual meaning. According to Nik Mohd Rahimi Nik Yusoff (2005), the ability in these two aspects support each other. However, the findings of his study show that students master the hearing comprehension contextually rather than lexically. One of the rationales of why students have more tendencies to use bilingual dictionaries compared to monolingual dictionaries is that they do not understand the given definition due to their lack of vocabulary knowledge. In this matter, bilingual dictionaries became an alternative to average students who prefer instant translation of the targeted words. Findings on the usage of bilingual dictionaries are different from the findings of a study conducted by al-Suwairekh (2001.) which found that students have higher tendency to use monolingual dictionaries. This is caused by the differences in the students' competencies and good linguistic environment.

Asking friends and teachers is equal to the study by Oxford \& Ehrman (1995) and Wharton (2000) which supported that this item is one of the most frequently used social strategies. It is popular and frequently used by students who have a low mastery level and often used to overcome listening weaknesses. This strategy item is different from the findings of research conducted by Kamarul Shukri (2009) which found that the strategy of asking for explanation or confirmation is used moderately in learning the Arabic language.

The pre-university students of SMKA and SABK are found to not frequently use the 12 VLS. Most of these strategies include strategies that require a high mental processing level and learning activities that entail exercises and repetition. Most of them do not depend on in-class learning activities. This shows that students do not prefer to use more challenging strategies. Strategies such as using monolingual dictionaries, testing oneself, making one's own definitions, writing in paragraphs are learning activities that require high linguistic competency and a large vocabulary.

In addition, there are a few strategies which describe the students as not interested in exploring strategies that require the aid of other materials like using flash cards, role playing, tests, media, social websites and textbooks. This might be caused by the absence of exposure at school level and lack of equipment. The usage of teaching aids plays an important role in the teaching and learning process (Mok, 1991). This was supported by the study by Nik Mohd Rahimi Nik Yusoff (2005) which found that the level of usage of teaching and learning for listening skills in the Arabic language is low.

\section{Conclusion}

The study conducted shows that the level of VLS usage is moderate for pre-university students. Only a few strategies are used at high frequency level such as using bilingual dictionaries, guessing the meaning, asking friends, asking teachers, ignoring inflections and memorizing words based on regularity. Meanwhile, other strategies having high impact in strengthening vocabulary learning are less used in learning Arabic vocabulary.

The usage of strategies in an incomplete manner and only focusing on a few strategies which are easy, quick, do not need in-depth mental processing, exercises and repetition will disturb the effectiveness of vocabulary learning. The usage of a variety of strategies will help in improving mastery of Arabic vocabulary. Active vocabulary learning involves two situations which are when discovering new words and how to strengthen existing knowledge. The failure of students to optimize the usage of VLS in both situations will affect their mastery of Arabic vocabulary in terms of size and understanding.

\section{References}

Ahmed, M. (1989). Vocabulary learning strategies. In P. Meara (Ed.), Beyond words (pp. 3-14). London: CILT.

al-Suwairekh, S. (2001). Vocabulary Learning Strategies Used by AFL (Arabic as a Foreign Language) Learners in Saudi Arabia. PhD Thesis, Universiti of Leeds, United Kingdom.

Bannett, P. (2006). An evaluation of Vocabulary Teaching in an intensive study programme. Unpublished MA Thesis, University of Birmingham, United Kingdom.

Brown, C., \& Payne, M. E. (1994). Five essential steps of processes in vocabulary learning. Paper presented at 
the TESOL Convention, Baltimore, MD.

Celik, S., \& Toptas, V. (2010). Telling ELT tales out of school: Vocabulary learning strategy use of Turkish EFL learners. Procedia - Social and Behavioral Sciences, 62-71. http://dx.doi.org/10.1016/j.sbspro.2010.07.013

Cohen, A. D. (1990). Language Learning: Insight for learners, teachers and researchers. New York, NY: Newbury House/Harper Row.

Cunningsworth, A. (1995). Choosing your coursebook. Oxford: Heinemann.

$\mathrm{Gu}$, P. (2005). Learning strategies: Prototypical core and dimensions of variation. Retrieved from http://www.crie.org.nz/research_paper/Peter_GU.pdf

Haron, A. I. (2008). Perception of Vocabulary Learning Strategies among ESL students in a selected secondary school in Melaka. Unpublished M.A Thesis, Bangi: Universiti Kebangsaan Malaysia.

Hsien-jen, C. (2001). The effects of dictionary use on the vocabulary learning strategies used by language learners of Spanish. University of Illinois, Urbana-Champaign.

Hunt, A. \& Belglar, D. (2005). A framework for developing EFL reading vocabulary. Reading in a Foreign Language, 17, 1-31.

Jemali, M. (1999). Hubungan antara gaya pembelajaran dengan pencapaian bahasa Arab Komunikasi sekolah menengah rendah di Negeri Perak. Research project: Universiti Kebangsaan Malaysia.

Kafipour, R. (2010). Vocabulary learning strategies, vocabulary knowledge and reading comprehension of EFL undergraduate students in Iran. Unpublished $\mathrm{PhD}$ thesis, Serdang: Universiti Putra Malaysia.

Kojic-Sabo, I., \& Lightbown, P. M. (1999). Students' approaches to vocabulary learning and their relationship to success. The Modern Language Journal, 83(2), 176-192. http://dx.doi.org/10.1111/0026-7902.00014

Lio, Y. (2002). A survey study of Taiwan EFL freshmans vocabulary learning strategies. Unpublished MA Thesis, National Changhua University of Education, Taiwan.

Macaro, E. (2005). Fourteen features of a language leaner strategy. Retrieved from http://www.crie.org.nz/ research_paper?Ernesto_Macaro_WP\$.pdf

Mohamad, A. H., \& Sulong, W. M. W. (2006). Antara minat dan sikap pelajar terhadap bahasa Arab: Satu kajian ke atas pelajar sarjana muda bahasa Arab di IPTA Malaysia. Wacana Pendidikan Islam (Siri 5) (pp. 9-18). Bangi: Fakulti Pendidikan, UKM.

Mok, S. S. (1991). Pedagogi 2: Strategi pengajaran dan pengajaran mikro. Kuala Lumpur: Kumpulan Budiman.

Nation, I. S. P (2001). Learning vocabulary in another language. Cambridge: Cambridge University Press. http://dx.doi.org/10.1017/CBO9781139524759

Nation, I. S. P. (1990). Teaching and learning vocabulary. New York, NY: Heinle \& Heinle.

Omar, A. (1984). Kaedah pengajaran bahasa. Kuala Lumpur: Dewan Bahasa dan Pustaka.

Oxford, R. (1990). Language learning strategies: What every teacher should know. Boston, MA: Newbury House.

Oxford, R. (2003). Language learning styles and strategies: An overview (pp. 1-25). Learning Styles \& Strategies/Oxford, GALA.

Oxford, R., \& Ehrman, M. (1995). Adults' language learning strategies in an intensive foreign language program in the United States. System, 359-385. http://dx.doi.org/10.1016/0346-251X(95)00023-D

Rouyan, N. M. (2004). Strategi pembelajaran Bahasa dalam pembelajaran bahasa Arab: Kajian di KUSZA. Unpublished MA Disertation, Bangi: Universiti Kebangsaan Malaysia.

Sahbazian, S. (2004). Perceived vocabulary learning strategies of Turkish University students. Unpublished Ph.D thesis, Oklahoma State University.

Salleh, W. N. W. M. (2006). Vocabulary Learning Strategies of good and poor ESL learners. Kuala Lumpur: University of Malaya.

Sarani, A., \& Kafipour, R. (2008). The relationship between extraversion/introversion tendencies of Iranian BA students of English and their English oral reproduction. Muenchen, Germany: Lincom GmbH.

Schmitt, N. (1997). Vocabulary learning strategies. In N. Schmitt, \& M. McCarthy (Eds.), Vocabulary: Description, acquisition, and pedadogy (pp. 199-227). Cambridge: Cambridge University Press. 
Schmitt, N. (2000). Vocabulary in Language Teaching. Cambridge: Cambridge University Press.

Shukri, M. T. K. (2009). Penggunaan stretegi pembelajaran bahasa Arab dalam kalangan pelajar sekolah menengah agama. Unpublished Ph.D Thesis, Bangi: Universiti Kebangsaan Malaysia.

Sokmen, A. (1997). Current trends in teaching second language vocabulary. In N. Schmitt, \& M. McCarthy (Eds.), Vocabulary: Description, acquisition, and pedagogy (pp. 237-257). Cambridge: Cambridge University Press.

Talib, A. A. A. (1996). Menguji kemahiran bahasa: Prinsip, teknik dan contoh. Kuala Lumpur: Dewan Bahasa dan Pustaka.

Tu'aymah, R. A. (1986). al-marja' fi ta'lim al-lughah li natiqin bi lughah ukhra. Macca: Ummu al-Qurra University.

Wharton, G. (2000). Language learning strategy use of bilingual foreign language learners in Singapore. Language Learning, 50(2), 203-243. http://dx.doi.org/10.1111/0023-8333.00117

Yusoff, N. M. R. N. (2005). Penilaian Kemahiran Mendengar dalam kurikulum bahasa Arab Komunikasi di sekolah-sekolah agama kerajaan negeri. Ph.D Thesis, Bangi: Universiti Kebangsaan Malaysia.

Zarafshan, M. (2002). Effects of attitude and motivation on the use of language learning strategies of Iranian EFL university students. Unpublished M.A thesis, Shiraz Azad University, Iran.

Zhang, B. (2009). FL Vocabulary learning of undergraduate English majors in western China: Perpective, strategy use and vocabulary size. English Language Teaching (p. 185). http://dx.doi.org/10.5539 /elt.v2n3p178

\section{Copyrights}

Copyright for this article is retained by the author(s), with first publication rights granted to the journal.

This is an open-access article distributed under the terms and conditions of the Creative Commons Attribution license (http://creativecommons.org/licenses/by/3.0/). 